\title{
LibGuides Groups in practice
}

\section{Building a partnership between an academic library and an information studies school}

$\mathbf{T}$ he University of California-Los Angeles campus is home to an iSchool and a robust library system, consisting of nine physical locations and even more affiliated library units. It would seem natural that the iSchool would partner with the library to provide library and Information Studies students with opportunities to learn practical skills to enhance their resumes.

While some partnerships do exist, such as providing traditional internship and job opportunities, and librarians teaching the occasional guest lecture in a course, we believe that there are missed opportunities that would benefit both students and librarians. In the project we created, two UCLA librarians worked with their campus ischool to provide a unique opportunity to teach students the LibGuides system using LibGuides Groups.

\section{Background on issue}

There has been an abundance of library literature referring to the current disconnect between the research and theory taught in LIS programs and the practice of librarianship. In 2004, former ALA President Michael Gorman pointed out that the "gap between what is taught in many LIS schools and what is being practiced in libraries is wide and widening." He called for a complete reform in LIS education, and points out how existing LIS programs tend to be at large, research universities, which "value (and reward) pure research over applied research."1
In addition, in his article, "Framing a Vision for 21st-Century Librarianship: LIS Education in Changing Times," James Elmborg calls for the technological proficiency of all LIS graduates. He asserts that, "...every student who graduates from an LIS program should be a power user of technology. We need to graduate students who use technology comfortably and as a natural part of their work lives." ${ }^{2}$

The UCLA iSchool curriculum is primarily built upon theory-based courses, requiring students to seek out hands-on skill building outside of the classroom via internships or job opportunities. Our partnership project with the iSchool instead helps to bring these opportunities into the classroom.

\section{Partnership}

In spring 2019, a professor at the UCLA iSchool and an instructional support staff member contacted the authors, cochairs of the UCLA Library's Research Guides Management Team (RGMT), about a potential partnership with the library. This iSchool staff member had recently obtained access

Courtney Hoffner is web and emerging technologies librarian, email: choffner@library.ucla.edu, Antonia Osuna-Garcia is health and life sciences librarian, email: aogarcia@library.ucla.edu, at UCLA Science Libraries

(c) 2020 Courtney Hoffner and Antonia Osuna-Garcia 
to use LibGuides for the iSchool's small internal library collection and had told the professor about the platform. The professor floated the idea to have students in her Performing Arts Librarianship class create subject or topic LibGuides as their final class project. As the iSchool does not have an individual subscription to LibGuides, they would have to gain access through the library's account, overseen by RGMT.

The library had never been contacted for such a partnership before, and the authors

of LibGuides just for the class, with its own look and feel, customization, and access.

The LibGuides Group functionality works within a LibGuides CMS subscription. The UCLA Library originally upgraded our subscription to LibGuides CMS in 2015 to take advantage of the CMS benefits, including enhanced A-Z database management, the use of surveys and forms, more customizable templates, and restful APIs. While those on our local LibGuides Management Team knew of the LibGuides Groups functionality, we didn't see much use for it at our institution, and therefore had not implemented its use beyond experimentation.

LibGuides Groups

LibGuides Assessment
Please let us know how the process went for you this quarter! Fill out ou assessment survey.

Choreographic Resources 6

Eorly Music o

Finding scores in the Music Library o

Gangsto Rap 0

Maria Irene Fornés

\section{Modern Jozz Innovators, 1990- o}

Music Films, Documentaries, \& Musicals

Puppet Theater 0

Welcome to LibGuides

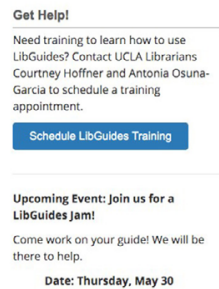

Date: Thursday, May 30 allows for customization among unique user groups. According to the Springshare website, LibGuides Groups allows libraries to create groups of guides with their own set of behaviors, including customizing the look and feel (including the CSS), displaying unique banners and footers, setting specific access control to the group, specifying granular user permissions, and even creating a unique LibGuides "homepage" for that particular group. ${ }^{3}$

Although Springshare does provide some examples of institutions using the Groups functionality, most subscribers do not take advantage of unique customization features. Currently, Groups are most often used for staff Intranet purposes or to highlight specific collections or subjects. ${ }^{4}$

In our project with the UCLA iSchool, we took full advantage of LibGuides Groups to create a unique set-up of LibGuides, which differed completely from our UCLA Library user guides.

The Performing Arts Librarianship set of LibGuides had their own customized home- 
page. This displayed a view of all the studentcreated guides, plus our "Welcome" guide, which detailed poli-

cies, procedures, and training resources. In addition, we provided links for training appointments and workshops, and our assessment survey.

After the guides were set up, an important piece of this project was to provide training to the students in how to use the LibGuides CMS. In addition to providing training resources through Springshare, we add-

\section{Gangsta Rap}

This library guide is designed to provide

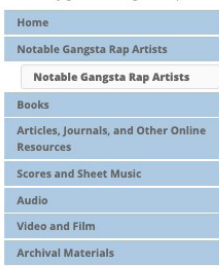

CDs Available at the Music Library

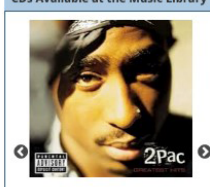

2Pac - Greatest Hits (1998) at hand to answer questions.

These trainings reinforced the necessity of ed our own LibCal

MyScheduler widget, which enabled students to schedule appointments with us for train-
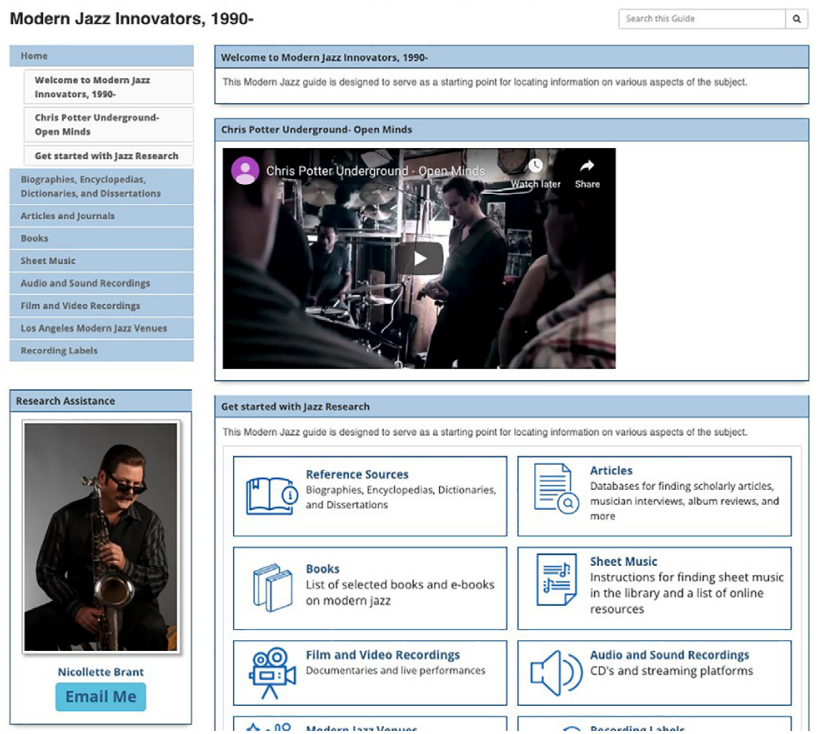

Student LibGuide with use of button navigation and media widget.

ing. We also scheduled a LibGuides "jam" for the students to attend, where they could work on their guides together, and we were teaching these skills to IS students, as many of them were unfamiliar with even basic web and content management skills.

At the end of the quarter, eight students presented their final projects (LibGuides) to their class. Topics ranged from puppet theater to gangsta rap to modern jazz innovators. Many of the students used the library's best practices, standardized templates, and database assets, along with their own designs. They also used many of the advanced functions of LibGuides featured in our trainings, such as tabbed boxes, media widgets, book covers, images, and button navigation.

\section{Results/assessment}

Feedback received from the professor, staff member, and students about this partnership was overwhelmingly positive. Almost every student we worked with remarked on how learning LibGuides was 
one of the most useful skills they had received so far in their program, and how they wished more classes would require similar projects. The professor mentioned to us after the course was over that she was very pleased with the guides the students created, and the help we provided them. We embedded a feedback form (using LibWizard) onto their LibGuides homepage, but we did not receive many responses. In the future, we will find another way to send this survey to the students and the professor to increase our response rate.

Another result of this partnership is that some UCLA subject librarians were so impressed with the content that they are considering incorporating the studentcreated LibGuides, or aspects of them, into our library's guides. This unintended result showed how such a partnership could also benefit the library.

\section{Future partnerships/conclusion}

This project allowed us to brainstorm new ways to partner with the iSchool. Some ideas we are considering include: creating LibGuides Groups for other courses, allowing IS students to use LibGuides for their final portfolio presentations, and creating a series of practical trainings open to all MLIS students.
This successful partnership has been fruitful in many ways. IS students learned practical skills to increase their job prospects and learned how to provide useful, creative content for users. UCLA librarians learned new ways to use their existing tools. As of fall 2019, another IS course has already inquired about using LibGuides for their final student projects.

In addition to these successes, we hope this partnership continues to grow and thrive to benefit student skills and foster librarian/ campus partnerships.

\section{Notes}

1. Michael Gorman, "Whither library education?" New Library World 105 , no.1204/1205 (2004): 376-380, https://doi. org/10.1108/03074800410557330.

2. James K. Elmborg, "Framing a Vision for 21st-Century Librarianship: LIS Education in Changing Times," The Serials Librarian 55, no.4 (2008): 499-507, https://doi. org/10.1080/03615260802385188.

3. "Organize with Groups," Springshare Buzz, accessed July 15, 2019, https:// buzz.springshare.com/producthighlights /whylgcms/groups.

4. "Live Sites Using Groups," Springshare Buzz, accessed July 19, 2019, https:// buzz.springshare.com/producthighlights /whylgcms/groups/examples. n

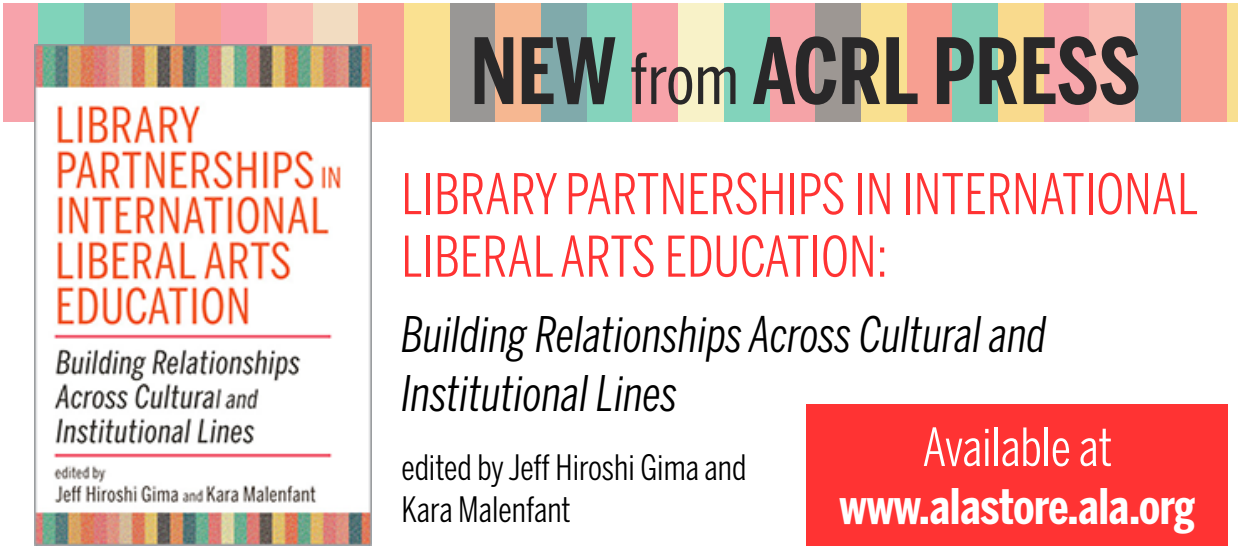

